\title{
Processing management in pomegranate fruit-A case study of squash making
}

\section{M.K. SHWETHA, K.S. THIPPANNA, BALACHANDRA K. NAIK AND N. SRINIVAS}

\begin{abstract}
The present study on processing management of pomegranate squash making was conducted in Koppal and Vijayapura districts of North Karnataka based on the highest area and production and higher concentration of pomegranate fruit processing units with the objective to analyze the value addition process and its economics. The results were based on primary data collected, with the sample size of twenty wholesalers cum commission agents, four processing units and twenty retailers from each district. The total cost incurred by the pomegranate squash processor, wholesaler- cum- commission agent and retailers in processing, storing, transporting and marketing hundred lit of squash was Rs. 8904, Rs. 211 and Rs. 102. The net price received by them after deducting marketing charges is accounted for Rs. 2298 , Rs. 1665 and Rs. 2400 per hundred liters, respectively. The extent of value addition was found to be 58 per cent along with the processors share in consumer's rupee to the tune of 57 per cent. Non-availability of infrastructure facilities like cold storage, grading and processing were the major problems faced by the value chain actors in its value addition and are the resultant of lower returns in value addition and its marketing. Therefore, suitable infrastructure facilities are essential to stabilize the returns of fruit growers and other value chain actors in fruits value chain, by increasing the storage life of the fruits by adding value to them in different ways by different value addition processes.
\end{abstract}

KEY WORDS : Value chain, Retailer, Squash making, Pomegranate squash

How to cite this paper : Shwetha, M.K., Thippanna, K.S., Naik, Balachandra K. and Srinivas, N.(2016).Processing management in pomegranate fruit - A case study of squash making. Internat. J. Com. \& Bus. Manage, 9(2) : 188-193. DOI: 10.15740/HAS/IJCBM/9.2/ 188-193.

\section{MEMBERS OF THE RESEARCH FORUM}

Correspondence to:

M.K. SHWETHA, Department of Agribusiness Management, College of Agriculture, University of Agricultural Sciences, DHARWAD (KARNATAKA) INDIA

Email: shwethamrutha@gmail.com

\section{Authors' affiliations:}

K.S. THIPPANNA, Department of Post Harvest Technology, College of Horticulture, BIDAR (KARNATAKA) INDIA

BALACHANDRA K. NAIK, Department of Agribusiness Management, College of Agriculture, University of Agricultural Sciences, DHARWAD (KARNATAKA) INDIA

N. SRINIVAS, Department of Horticulture, College of Horticulture, BIDAR (KARNATAKA) INDIA 